\title{
FINANCIAL AND ECONOMIC MECHANISM OF NATIONAL FOREST POLICY IMPLEMENTATION
}

\author{
Chernyakevich Lidiya Mikhailovna* \\ Volga State University of Technology, Russia \\ Andrianov Yuryi Semyonovich \\ Volga State University of Technology, Russia
}

\begin{abstract}
Approaches to understanding the essence of the notion of 'forest policy' are systematized. The contents of the state policy is covered from the view point of forest exploitation, control, protection and reproduction in the Russian Federation on the basis of concept, principles, strategic and tactical purposes of forest management. The features of the financial and economic mechanism are revealed in the field of forest relations under the conditions of federal property on forest plots in the structure of forestry fund lands and private-entrepreneurial form of forest exploitation. A fundamental law of forest exploitation in Russia is rent of forest plots, therefore the financial and economic mechanism of national forest policy implementation should be based on coordination of interests of the state (the proprietor of forest fund), business (in forest exploitation) and the population living on forested territories or near the forests. The conceptual scheme of financial and economic mechanism in the field of forest exploitation, control, protection and reproduction is developed. Such instruments of forest policy as forest planning, price system in the forest sector of economic activity, subventions on the execution of powers transferred to subjects of the Russian Federation in the field of forest relations, subsidies for a state (municipal) establishment to perform the state task services in the sphere of natural resources reproduction and exploitation are con-sidered. The basic trends of the state industrial and national forest policies aimed at the development of the forest sector of the economics of Russia are generalized.
\end{abstract}

Key words: Smart maintenance; Proactive maintenance; Technical Diagnostics; Digitalization; Industry 4.0; Logistics 4.0; Handling solutions

\section{INTRODUCTION}

Forests are a strategic natural renewed resource of Russia as both ecological system and a resource for social and economic development. Extensive forest exploitation in the past, imbalance inside the forest sector between logging and deep processing, absence of interest of private businesses in complex zero waste wood products manufacture, problems in financing of forest reproduction testify to the necessity of carrying out research into financial and economic aspects of management in the field of forest exploitation, control, protection and reproduction. In the period of transformations, the system of state forest management has repeatedly been reformed using administrative methods, thus economic management methods and economic substantiation of the decisions made has not found due application so far. In the forest sector, including state forest management, forestry and forest industry branches, there appear new problems of develop-ing mutually advantageous economic relations between the state, which is the proprietor of the forest fund, businesses engaged in forest exploitation, and the population living on forested terri-tories or near the forests. The relevance of the problem of development a financial and economic mechanism for implementation of national forest policy according to the principles of sustainable forest management, ecological, social and economic efficiency determined the purpose and the objectives of the research.

The purpose of the work is to work out theoretical and practical aspects of developing a fi-nancial and economic mechanism for implementation of the national forest policy of Russia aimed at sustainable forest management.

Objectives. According to the purpose of the research, the following tasks have been completed: 
- methodological provisions of the financial and economic mechanism for realization of na-tional forest policy have been determined;

- financial and economic aspects of the system of forest relations under modern conditions have been analyzed and the conceptual scheme of a financial and economic mechanism in the field of forest exploitation, control, protection and reproduction has been developed according to forest and industrial policies of Russia;

- theoretical and applied aspects of developing a financial and economic mechanism for the national forest policy implementation have been worked out.

Methodological provisions. In mixed economy, occurring within the period of transitional development of social and economic system of Russia, the market, alongside with active position of the state, is another mechanism of regulating financial and economic relations in the field of forest exploitation, control, protection and reproduction, forest plots in the structure of the forest grounds fund being the federal property.

Forest policy development and forest management strategy in contemporary Russia are considered by such national scientists as A.I. Isayev, N.A. Moiseyev, A.I. Pisarenko, V.V. Strakhov, A.P. Petrov, V.N. Petrov, V.K. Rezanov and others. Forest management strategies implemented through forest policy are studied by foreign scientists and experts P. Alkhoyarvi, X.Virten, P. Veiola, John A. Grey, Peter X. Piers, A. Carcenti, G. Diterle, R. Stripnieks, M. Sutter and others.

A.P. Petrov considers forest policy to be the system of strategic political decisions on crea-tion of political, economic and social conditions in the sphere of sustainable forest management, accepted on the national level through coordination of interests of the state, the business and the society [10]. N.A. Moiseyev defines this as follows, 'National forest policy constitutes the gen-eral conception of the state on its forests (regardless of the ownership structure in this or that country) which is expressed in posing purposes and objectives, choosing the ways, means and mechanisms of their implementation... It is national forest policy within it that should develop forms and conditions of legal environment for its implementation' [09]. V.N. Petrov defines the mechanism of forest policy as integral hierarchic system of state bodies and establishments which exercise power in practice, executing the tasks and per- forming the functions of the state in the fields of forestry and forest industry [11]. Finnish experts P. Riihinen, I. Tikkanen see the essence of forest policy in 'influencing the activity of people, rather than managing forest re-sources exploitation directly to reach the goals set' [08].

Thus, forest policy is the policy of a state in the field of forest exploitation, control, protec-tion and reproduction captured in legislative and regulatory acts and implemented through the system of state forest management. The elements of forest policy include the role of the forest as environmental resource and key factor of social and economic development of a state, fundamentals, goals, objectives and mechanisms of their implementation in the field of forest use, con-trol, protection and reproduction. Besides, provisions of international conventions and treaties signed by Russia exert a significant impact on the development of national forest policy [09, $13,12,02]$.

Forest policy is not considered a static system, rather an open dynamic system formed ac-cording to the state policy in the field of federal relations and economic policy as well. The au-thors studied historical stages of economic aspects of the state forest management in [03, 01, 04].

Principles, purposes and objectives of the state in the field of forest exploitation, control, preservation and reproduction, as well as the mechanisms of their implementation are determined by the document 'Bases of the state policy in the field of forest exploitation, control, protection and reproduction in the Russian Federation for the period up to 2030'. The principles are substantive provisions and rules the national forest policy is based on (Figure 1).

At present, the state policy in the field of forest exploitation, protection, control and repro-duction is directed at preservation and augmentation of forests, maximum satisfaction of Russian citizens' needs in qualitative products and useful properties of forests, as well as creation on a national level of the conditions providing steady and dynamic development of the forest sector of economics. Financial and economic policy methods and instruments should be directed at the implementation of the main principles of state policy having in view the peculiarities of their implementation in the forest sector. 
BASES OF THE STATE POLICY IN THE FIELD OF FOREST EXPLOITATION, CONTROL, PROTECTION AND REPRODUCTION IN THE RUSSIAN FEDERATION

Balance of economic, ecological and social interests

Multi-purpose and sustainable forest exploitation

Federal property of forests while strengthening the role of private investments into the sector

Taking into account social and economic, natural and climatic as well as environmental peculiarities of the subjects of the Russian Federation

Enhancing the role and competitiveness of the Russian Federation in the global forest sector

Figure 1: Basic principles of state policy in the field of forest exploitation, control, protection and reproduction in the Russian Federation [06]

The vector of economic activities development of social and economic system of the state is determined by the economic policy fixed in normative and judicial documents. It is methodolog-ically important to make economic policy classification of the state according to sectoral attrib-ute: agrarian, industrial, food, forest, ecological and other kinds of economic policy; functional attribute: monetary and credit, tax (fiscal), investment, external economic, innovative, etc. Hence, market self-regulation of economic activities functions in rigid institutional conditions, where financial and economic relations are realized in view of sectoral features within the framework of economic policy of the state.

Financial and economic stability of forestry is defined not only in terms of decision-making efficiency in the sphere of forest relations, the timber complex including woodworking and pulp and paper industry has the major value as well. In this respect, the purposes, objectives, fiscal instruments and other aspects of economic activities in timber complex should be considered in the context of forest and industrial policies. The financial and economic mechanism in the field of forest relations (Fig. 2), as a set of fi-nancial and economic methods, ways, forms, instruments for realization of forest policy at the federal level and the level of other subjects of the Russian Federation, has undergone major mod-ifications during the period of the economy transformation. Economic activities in forest industry are conducted by private businesses and, accordingly, market mechanisms of self-regulation in the generated institutional environment are involved. In addition, economic methods of forest management are developed and applied to the practice of forestry management with difficulties.
To implement the state policy in the field of forest exploitation, control, protection and re-production it is necessary to reach the following goals [06]:

a) In the economic sphere - Efficient forest sector management and increase in gross domes-tic product in the forest sector based on market demand;

b) In the ecological sphere - Favorable environment for citizens and preservation of biosphere role of the forests of Russia;

c) In the social sphere - Growth of a standard of living for the citizens connected to forests, and sustainable social and economic development of forest territories.

The concept of green economy is considered to be a new approach to sustainable develop-ment at the international level. UNEP (United Nations Environment Program) defines green economy as 'the economy which raises people's well-being and provides social justice essentially reducing risks for the environment and its deterioration' [15]. Therefore, the strategic approach to sustainable forest management should be based on coordination and interdependence of the mentioned above purposes of national forest policy. In the short run, achieving maximum effect from exploiting forest resources due to the increase in volumes according to the type of exploitation, intensity of use and forests reproduction is considered promising in forest manage-ment.

Forestry Code of the Russian Federation introduces a new instrument of forest planning, which is the forest plan of the subject of the Russian Federation. An innovation of forest plan-ning at the level of the subjects of the Russian Federation is planning forest manage- 
ment and development in the region. Estimation of economic efficiency of performing actions on implementation of planned development of forests is contained in a separate section of a model form of the forest plan of the subject of the Russian Federation. This section includes financial and economic substantiation of activities, i.e. predicted incomes from forest development according to the types of exploitation and predicted volume of expenses on the activities planned; planned volume of private investments; parameter of profitability of forest development. The forest plan of the subject of the Russian Federation is scheduled for 10 years. The experience of forest plans development and their implementation with regard to economic substantiation testifies for insuf-ficient extent of development of forest products market forecasting problem in coordination with forest resources forecasts.

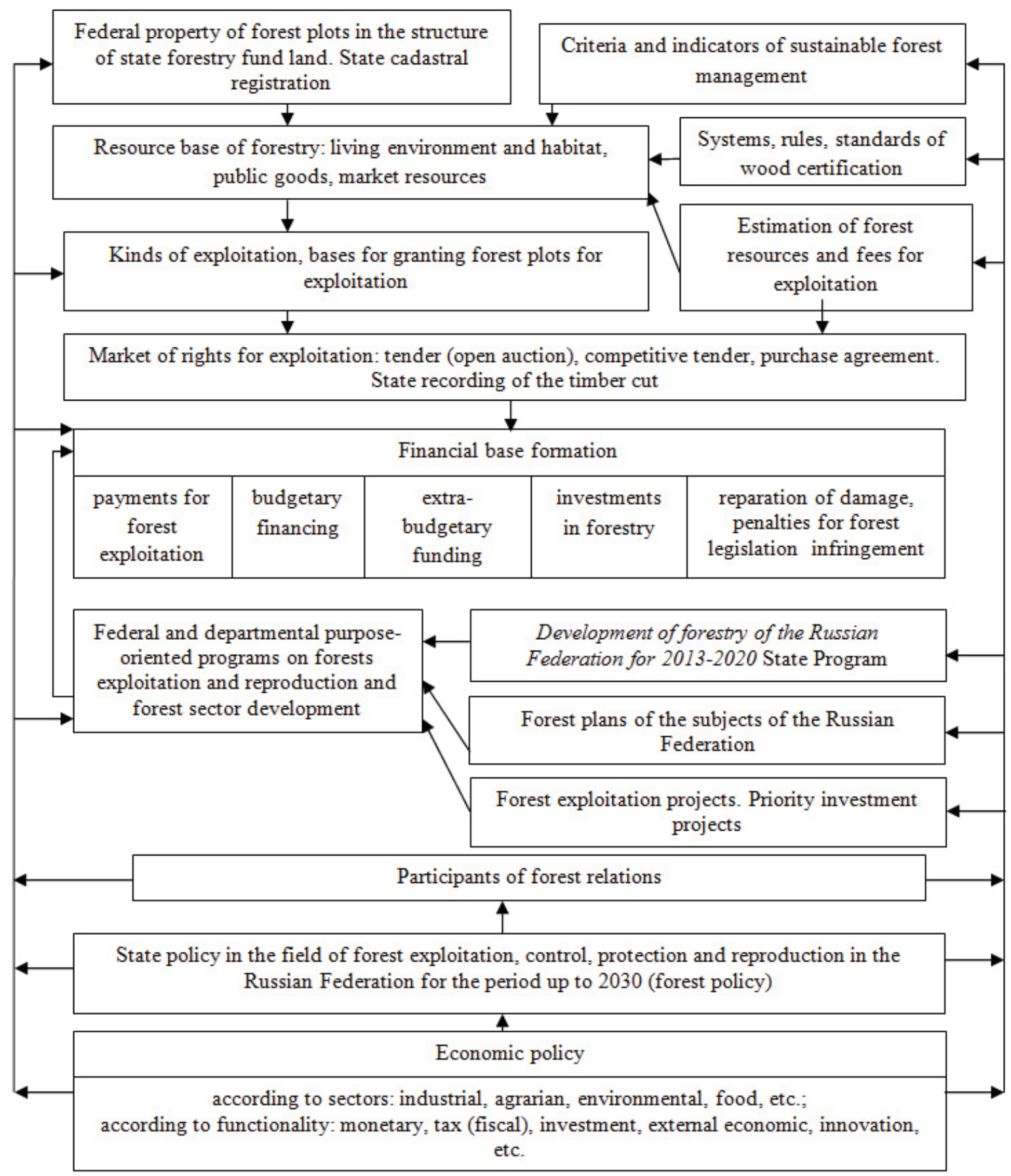

Figure 2: Conceptual scheme of a financial and economic mechanism in the field of forest exploitation, control, protection and regeneration 
Analytical research. Let us consider financial and economic instruments of forest policy implementation. The hierarchy of state forest management is characterized by distribution of powers between the federal level of management, the subjects of the Russian Federation and the opportunity of delegating authorities to the bodies of local management. Financing of the latter is made from the federal budget in the form of subventions. The subventions from the federal budget given to the budgets of the subjects of the Russian Federation (Art. 83, Forest code of the Russian Federation) are distributed depending on the area of exploitable forests, protective forests, intensity of their exploitation, population living on the territories of the subjects of the Russian Federation, forest fire characteristics according to the technique authorized by the Government of the Russian Federation.

One of the basic instruments of the financial and economic mechanism of national forest policy implementation is formation of a uniform price system at all stages of forest resources utilization and processing, including wood. Expenses on forest resources reproduction include expenses on forest growing, guarding, protection and forestry management. For reproduction of forest resources, it is necessary to commensurate these expenses with payments for their exploi-tation (principles of serviceability and profitability). Given this, the amount of charge for forest resources exploitation is included into the cost price of logging, and the cost of the timber cut is regarded as raw material and materials in the structure of woodworking product cost. Therefore the end product price level, in particular, from wood raw material, should determine the size of payment for forest resources.

The idea of withdrawal of the investment income for the benefit of a society belongs to academicians V.S. Nemchinov and D.S. Lvov. However, the method of rent taxation in the field of natural resources exploitation, allowing to withdraw rent for the benefit of a society, has not been applied so far. We consider that coordination of economic interests of the proprietor of for-est fund (state) and forest users (private business) can be achieved in determining prices for wood resources, based on the rent approach.

Payments for forest exploitation are received by the budgets at different levels. The increase in the forest income of budgets in Development of forestry state program is foreseen due to development of wood and paper-based products home market, including consumer goods produc-tion incentive, ecosystem services market shaping and development of the mechanisms of state purchase of wood and paper-based products, wood for the latter harvested on the forest plots managed sustainably [05].

Globally, Food and Agricultural Organization (FAO) has carried out research into the state of world forests for augmentation of forest-provided social and economic benefits [14] and showed the role of forests for food safety provision at global and national levels. Using non-timber forest resources (berries, medical plants, mushrooms, nuts, etc.) and forest service expands the fields of forest exploitation.

In Russia, lease relations between the state (the authorized bodies) and the business with view of various fields of exploitation (wood harvesting, recreational services, etc.) has been de-veloping dynamically since $1990^{\text {th }}$.

Under the conditions of state ownership of the forest fund and private-entrepreneurship form of managing, the forest plots lease to implement different fields of exploitation is the mechanism of state-private partnership in the field of forest exploitation, control, protection and reproduction. The project of forest development is an instrument of leaseholder forest planning. It should be directed at sustainable development of territories. Therefore, estimation of economic and social and economic efficiency of forest development on a forest plot should become an important component of the project, alongside with planning the activities on forest exploitation, control, protection, reproduction and creation of objects of forest and wood-processing infrastructure. Significant volumes of forestry works are assigned to leaseholders of forest plots at their own expense.

Implementation of priority investment projects by leaseholders of forest plots is the major direction of development of state-private partnership. Preferences to the investors implementing priority investment projects in the field of forests development established by the Government of the Russian Federation is a stimulus for giving an investment project in the field of forests development the status of priority. This means that forest plots are leased without participation in an auction on receiving such a right; lease payment 
privilege in the amount of $50 \%$ is given for the term of recoupment of the project [1]. This given, the state should create conditions for solv-ing infrastructural problems: transport, industrialpower and social.

Improvement of forest management effectiveness (economic, ecological, and social) depends on sustainable development of forest sector of economics. One of the primary goals of state policy in the field of forest exploitation and reproduction is increase of competitiveness of forest industry, including increase in manufacturing wood and paper production with high added value, maximum satisfaction of home market needs in high-quality forest products processed domestically and their export.

The task specified above is consistent with the primary goals of industrial policy, i.e. stimu-lating demand, increasing competitiveness and technological modernization. Directions and instruments for state support of achieving primary goals of industrial policy include stimulation of home consumption, import substitution, support of export, tax privileges, stimulation of technical development, state-private partnership and others [07].

Financing operations on forest control, protection and reproduction on non-leased forest plots is executed through government (municipal) procurement for their performance by tender-ing. Placement of an order is carried out simultaneously with sale of forest plants for wood har-vesting. The volume of the subsidy for financial provision of the state task execution on render-ing state services (performing of works) to state (municipal) budgetary and independent estab-lishments in the sphere of reproduction and exploitation of natural resources is determined on the basis of normative expenses for their execution.

Solution to the problem of increasing scientific and technical, technological and personnel potential of the forest sector of economics provides for the following $[7,5]$ :

a) Creation of conditions for modernization of wood science and education;

b) Integration of wood science and education on the basis of creating innovative technologi-cal centers, scientific and educational clusters, technological parks, industrial networks, etc.;

c) Creating the environment for commercialization of scientific research results and intro- duc-tion of innovative scientific and technical production into forest sector of economics;

d) Creation of the system of educating and professional skills developing for heads of organ-izations and experts of the forest sector of economics.

\section{DISCUSSION}

The purpose of the research consists in development of theoretical and practical aspects of forming the financial and economic mechanism for implementation of national forest policy of Russia aimed at sustainable forest management.

In mixed economy, market self-regulation of business processes functions under rigid insti-tutional conditions within the framework of economic policy. Financial and economic relations are implemented according to the nature of industry. Forests as ecological system and a resource for social and economic development are a strategic natural renewed resource of Russia. Forestry as a kind of economic activity should take into account silvicultural and biological characteristics of forests and economic conditions generated in the institutional environment of the state at a certain stage of development.

The base of economic relations in the social and economic system of a state is the property. Forestry code of the Russian Federation stipulates federal property of forest plots in the structure of forest fund. According to the forest legislation, state functions of management in the field of forest exploitation, control, protection and reproduction are fixed at a federal level, a number of authorities are delegated to the subjects of the Russian Federation, and the municipal level man-agement can also be given certain powers. Thus, powers rather than objects of property are dis-tributed in an organizational management structure. Financing the state functions execution is made from the budget, while the subjects of the Russian Federation receive subventions.

Improving the financial and economic mechanism of the national forest policy and its adap-tation to the purposes and problems of state economic policy should be directed at implementa-tion of social, ecology and economy goals of sustainable development. Financial and economic sustainability of forestry is determined not only by the efficiency of administrative decisions made in the sphere of forest relations; the sphere of timber complex has the major value as well. In 
this respect, goals, problems, financial instruments and other aspects of business activity in timber complex are to be considered in the context of forest and industrial policies.

The following factors of forest sector sustainable development are considered key ones: ef-fective multi-purpose resource exploitation and ecological system forest utilities, investment in forests reproduction, complex rational exploitation of forest resources, increase in a share of pro-duction of forest sector with high added value, innovative technologies, increase of scientific and technical and personnel potential of the sector.

\section{CONCLUSION}

The organization and the financial mechanism of forestry management during the period economy transformation in Russia have repeatedly changed. The state-private partnership in the field of forests development is implemented in the right of forest plots lease and in the form of priority investment projects with the measures of state stimulation. The activities on forest pro-tection and reproduction on non-leased forest plots are carried out through a state task to budget-ary and independent establishments or through the tenders to commercial organizations with simultaneous sale of plants.

Hence, in forestry management and state management in the field of forest exploitation, control, protection and reproduction a complex financial and economic mechanism is formed, which is submitted by the conceptual scheme in the research. The financial and economic mechanism in the field of forest relations includes methods and instruments of budgetary process and economic (market) mechanisms of self-regulation.

\section{ACKNOWLEDGEMENT}

We acknowledge the support from the Russian Humanitarian Science Foundation and the Republic of Mari El within the framework of the regional local competition Volga region territo-ries in the culture and history of Russia 2015 - the Republic of Mari El under grant agreement No 15-12-12006 'Transformation of reproduction processes in the forest sector of economics of the Republic of Mari El in the innovative development environment: traditions, history, prospects'.

\section{REFERENCES}

1) Chernyakevich, L.M. Forming economic mechanism for forestry management under the conditions of forest plots lease [Text] / L.M. Chernyakevich, T.M. Mal'kova // Vestnik of the Volga State University of Technology. Scientific journal. Economics and Management Series. - 2013. - No 1. - Pp.57-65.

2) Chernyakevich, L.M., Andrianov, Yu.S., Mochayeva, T.V. Methodological bases for sustainable forest management monitoring // Journal of applied engineering science, 14(2016)2, 306-313.

3) Chernyakevich, L.M. Priority investment projects in the field of forest development as the institute of forestry intensification in Russia. / L.M. Chernyakevich, T.V. Mochayeva // Scientific Journal of KubSAU, 2015. - 109 (05). URL: http://ej.kubagro.ru/2015/05/pdf/75.pdf - 17.06.2016.

4) Chernyakevich, L.M. Structural and economic reforms in the system of state administration and forestry management / L.M. Chernyakevich. - Yoshkar-Ola: MSTU publishing of-fice, 2004. - $260 \mathrm{p}$.

5) Forestry development for 2013-2020 State Program of the Russian Federation // Order of the Government of the Russian Federation of 15 April 2014. No. 318. URL: http://www. consultant.ru/ - 17.06.2016.

6) Fundamentals of state policy of the Russian Federation in the field of forest use, control, preservation and reproduction up to 2030 // Order of the Government of the Russian Federation of 26 September 2013 No. 1724-p. URL: http://www.rosleshoz.gov. ru/docs/other/83/osnovi_gospolitiki_0110. pdf - 17.06.2016.

7) Industry development and improving its competitiveness State Program of the Russian Federation // Order of the Government of the Russian Federation of 29 August 2013. No. 1535-p - URL: http://www.garant.ru/ 17.06.2016.

8) Integrated forest management based on its sustainable multi-purpose use under the con-ditions of market economy: Proceedings of the IUFRO Conf. - M.: VNNIILM Publishing office, 1993. $-280 \mathrm{p}$.

9) Moiseyev, N.A. National forest policy of Russia: its essence and the ways of realiza- 
tion URL: http://www.lesvesti.ru/news/expert/2115. - 17.06.2016

10) Petrov, A.P. Forest policy of the Russian Federation: better late than never Moscow state forest university bulletin - Lesnoy vestnik. - 2012. - 4(87). - Pp. 171-178.

11) Petrov, V.N. Forest policy and forest law. Saint Petersburg State Forest Technical University Publishing office, 2015. - $216 \mathrm{p}$.

12) Pisarenko, A.I., Strakhov, V.V. On the forest policy of Russia / A.I. Pisarenko, V.V. Strakhov - 2-d edition - M.: Jurisprudence Publishing house, 2012. - $600 \mathrm{p}$.

13) V.K. Ryazanov et al; ed. by V.K. Ryazanov, K.V. Ryazanov. Management mechanisms for forest complex sustainable development I - Vladivostok: Dal'nauka, 2015. - 511 p.
14) State of the World's Forests: Augmentation of Social and Economic Benefits Provided by Forests. / Food and Agricultural Organization of the United Nations. - FAO, Rome, 2014. URL: http://www.fao.org/3/a-i3710r.pdf - 17.06.2016.

15) Towards green economy: ways to sustainable development and eradication of poverty - the generalizing report for representatives of power structures, UNEP, 2011. - URL: http://www.unepcom.ru/wdownloads/ger synthesis_ru.pdf - 17.06.2016

Paper sent to revision: 25.08.2016.

Paper ready for publication: 17.11.2016. 